Article

\title{
Target-Guided Isolation of Three Main Antioxidants from Mahonia bealei (Fort.) Carr. Leaves Using HSCCC
}

\author{
Weicheng $\mathrm{Hu}^{+}{ }^{+}$, Jing Zhou ${ }^{\dagger}$, Ting Shen * and Xinfeng Wang * \\ Jiangsu Collaborative Innovation Center of Regional Modern Agriculture \& Environmental protection/Jiangsu \\ Key Laboratory for Eco-Agricultural Biotechnology around Hongze Lake, Huaiyin Normal University, \\ Huaian 223300, China; hu_weicheng@163.com (W.H.); zhou_scu@foxmail.com (J.Z.) \\ * Correspondence: shenting1019@163.com (T.S.); wangxf@hytc.edu.cn (X.W.); Tel./Fax: +86-517-8352-5992 (T.S.) \\ † These authors equally contributed to this work.
}

Academic Editors: Susana M. Cardoso and Alessia Fazio

Received: 1 May 2019; Accepted: 15 May 2019; Published: 17 May 2019

\begin{abstract}
Mahonia bealei (Fort.) Carr. is an economically important plant that is widely cultivated in Southwest China. Its leaves are commonly used for tea and contain an abundance of antioxidant compounds. However, methods of the systematic purification of antioxidants from M. bealei are lacking. In this study, antioxidants from this plant were effectively and rapidly enriched. First, antioxidants were screened using online 1,1-diphenyl-2-picryl-hydrazyl radical (DPPH)-high performance liquid chromatography (HPLC), followed by separation using high-speed countercurrent chromatography with an optical solvent system composed of $n$-hexane/ethyl acetate/methanol/water $(1: 5: 1: 5, \mathrm{v} / \mathrm{v} / \mathrm{v} / \mathrm{v})$. Three phenolics—chlorogenic acid $(\mathbf{1}, 8.3 \mathrm{mg})$, quercetin-3-O- $\beta$-D-glucopyranoside $(2,20.5 \mathrm{mg})$, and isorhamnetin-3-O- $\beta$-D-glucopyranoside $(3,28.4 \mathrm{mg})$-were obtained from the ethyl acetate-soluble fraction $(240 \mathrm{mg}$ ) by one-step separation. The chemical structures of the phenolics were characterized by MS and NMR techniques, and the purity of each compound was $>92.0 \%$ as determined by HPLC. The isolated compounds were assessed by scavenging activities on DPPH and superoxide radicals as well as cytoprotective assays, all of which showed similar trends regarding the antioxidant capacities of the compounds. Moreover, compounds 1-3 significantly attenuated the lipid peroxidation and antioxidant enzyme activities in $\mathrm{H}_{2} \mathrm{O}_{2}$-treated RAW264.7 cells. Our study demonstrated the efficiency of a newly developed integrative system for the comprehensive characterization of pure compounds from $M$. bealei, which will allow their use as reference substances.
\end{abstract}

Keywords: Mahonia bealei (Fort.) Carr.; DPPH-HPLC; HSCCC; antioxidant activity

\section{Introduction}

Oxidation is an essential biological process that participates in energy production in living organisms [1]. However, the consequences of excessive cellular levels of free radicals are relevant to the oxidation of biomolecules, leading to tissue damage, cell death, or degenerative processes including aging, cancer, cardiovascular diseases, heart diseases, and inflammation [2,3]. To reduce oxidative damage exogenously, many synthetic antioxidants have been developed, but their use is highly restricted because of their potential health hazards, including liver damage and carcinogenesis $[4,5]$. Thus, the effective exploitation and applications of natural antioxidants are of current interest [6,7].

Kudingcha tea is traditionally used in China and southeastern Asia, where its antioxidative capacity is well recognized [8]. Mahonia bealei (Fort.) Carr is a member of the Berberidanceae family and is widely distributed in the mountainous areas of southern China. It is included in the Chinese Pharmacopoeia as a Chinese folk medicine for the treatment of dysentery, jaundice, periodontitis, 
and bloody urine $[9,10]$. Its leaves, which in China are consumed traditionally as a bitter tea, contain antioxidant, anti-proliferation, anti-inflammatory, anti-bacterial, and anti-influenza activities [11,12]. However, the pharmacological testing of the leaves has been conducted mainly on extracts of the plant, such that its chemical constituents and their pharmacological activities have yet to be investigated. The present study is a detailed, target-guided chemical investigation of $M$. bealei leaves.

To our knowledge, this is the first published report on the separation and purification of phenolic antioxidants from M. bealei (MBE) leaves using high-speed countercurrent chromatography (HSCCC). As part of our ongoing investigation of antioxidants in natural products, we established an efficient and simple method of rapidly preparing antioxidants from $M$. bealei leaves using online 1,1-diphenyl-2-picryl-hydrazyl radical (DPPH)-high performance liquid chromatography (HPLC) coupled with HSCCC. Chlorogenic acid (1), quercetin-3-O- $\beta$-D-glucopyranoside (2), and isorhamnetin-3-O- $\beta$-D-glucopyranoside (3) were obtained (Figure 1 ). The presence of the latter two compounds in this plant is reported here for the first time. In addition, the antioxidant capacity of the isolated compounds was evaluated in an initial report on the systematic isolation and evaluation of antioxidants in M. bealei leaves. The analytical method described within will facilitate the development of pure compounds from this plant to serve as reference substances.

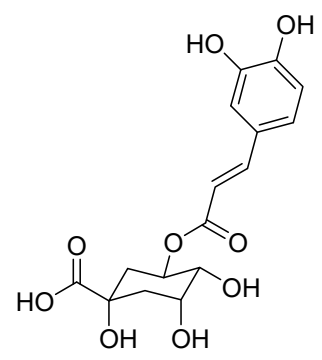

Chlorogenic acid

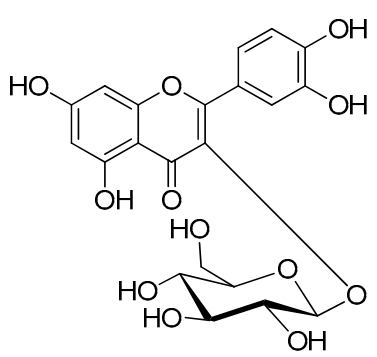

Quercetin-3-O- $\beta$-D-glucopyranoside

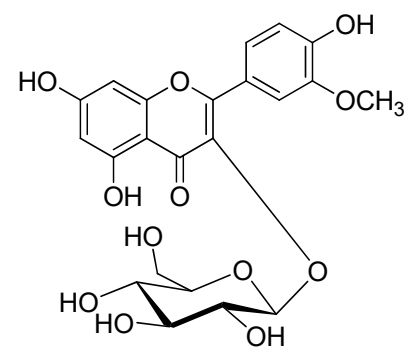

Isorhamnetin -3-O- $\beta$-D-glucopyranoside

Figure 1. Chemical structures of three compounds obtained from Mahonia bealei (MBE) leaves using high-speed countercurrent chromatography (HSCCC).

\section{Results and Discussion}

\subsection{Screening of Antioxidants by DPPH-HPLC}

The ethyl acetate fraction of the $M$. bealei leaves showed a potent capacity to scavenge DPPH radicals, with an $\mathrm{IC}_{50}$ of $32.95 \mu \mathrm{g} / \mathrm{mL}$ (data not shown). Thus, successive DPPH-HPLC and HSCCC experiments were carried out using this fraction to screen and isolate antioxidants.

The DPPH-HPLC method enables the rapid screening of antioxidants from complex mixtures, particularly natural products, with minimum sample preparation [13]. After the compounds of interest are reacted with DPPH, their peak areas in the HPLC chromatogram reduce or disappear if they contain antioxidant activity, whereas the peak areas of compounds without antioxidant activity remain essentially unchanged [14]. Untreated and DPPH-treated ethyl acetate fraction of M. bealei leaf extract (MBE) was processed according to the optimized separation conditions described above and then analyzed by HPLC. A comparison of the HPLC chromatograms of the untreated and DPPH-treated samples indicated three peaks $(1,2$, and 3$)$ with retention times of $6.99,22.32$, and $28.55 \mathrm{~min}$, respectively. The areas of the three peaks were smaller in the samples spiked with DPPH (Figure 2A), indicating that all three compounds are antioxidants. Then, HSCCC was used to isolate and purify these active compounds. 
A

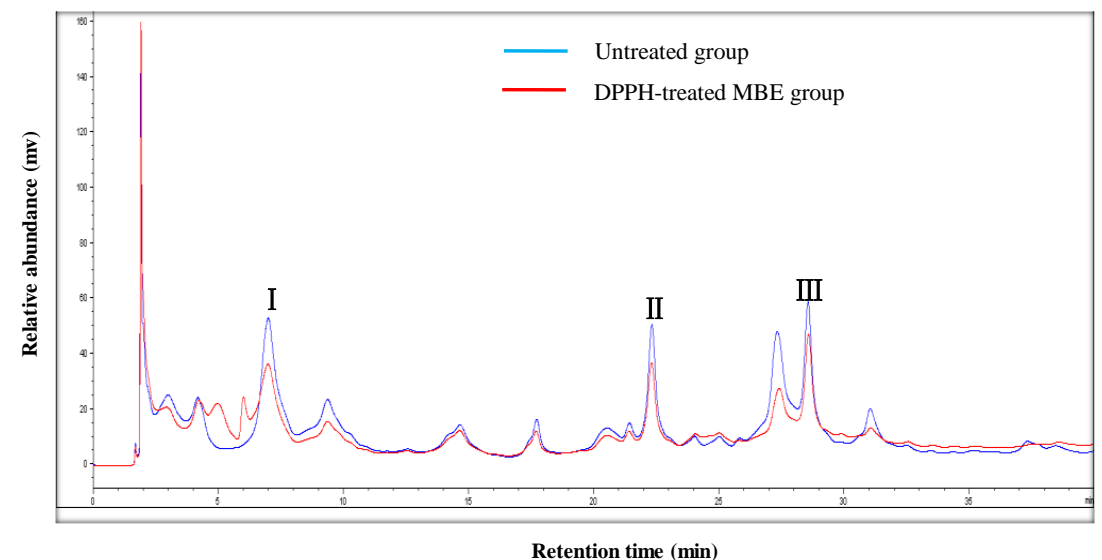

B

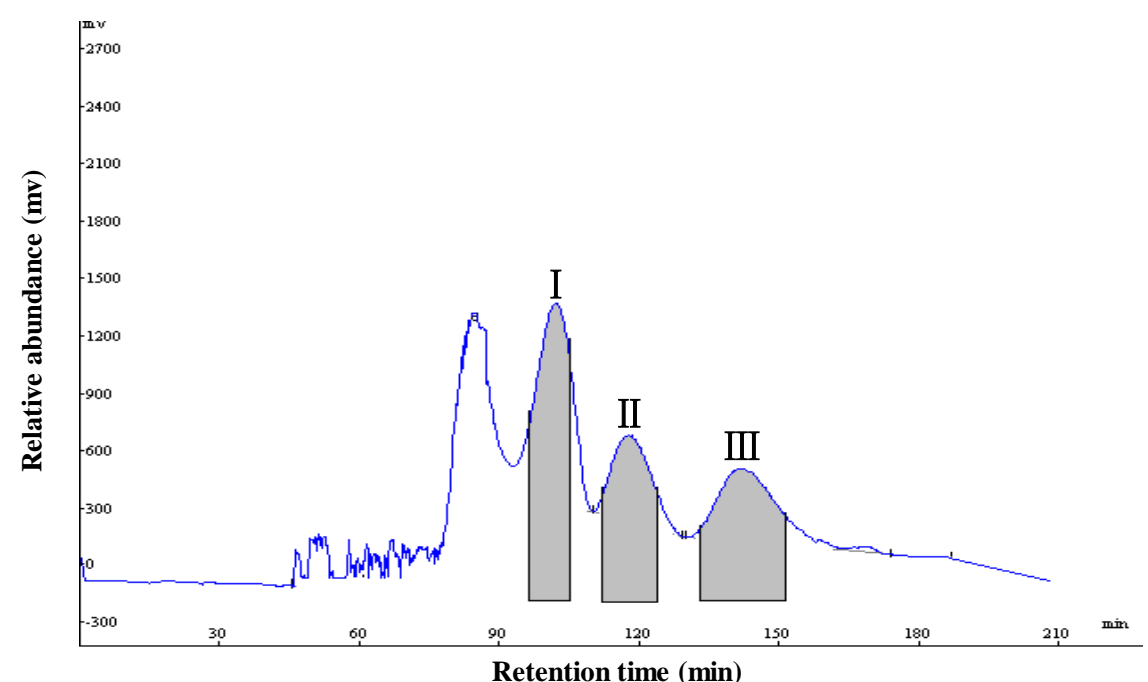

Figure 2. High-performance liquid chromatography (HPLC)-UV and 1,1-diphenyl-2-picryl-hydrazyl radical (DPPH)-HPLC-UV of an ethyl acetate fraction of M. bealei leaf extract (MBE) (A). HSCCC chromatogram of MBE using the $n$-hexane/ethyl acetate/methanol/water (1:5:1:5, v/v) solvent system (B).

\subsection{HSCCC Separation and Peak Fraction Analysis}

In HSCCC-based separation, the selection of a suitable two-phase solvent system is the most vital process. The appropriate biphasic system can provide an ideal range of the partition coefficient $(K)$ for the target compounds, whose value is usually considered in the range of 0.5 to 2.0 [15]. In this experiment, four different volume rations of a two-phase solvent system of $n$-hexane/ethyl acetate/methanol/water were tested to obtain the optimum composition. The resulting $K$ values of the target compounds are summarized in Table 1 . The $n$-hexane/ethyl acetate/methanol/water solvent system used at a ratio of 1:1:1:1 ( v/v/v/v) yielded low $K$ values for the three compounds. At a ratio of 1:5:1:2, the $K$ values were suitable for the separation of compounds $\mathbf{1}$ ( $K$ value: 0.73 ) and 2 (1.03), but not compound 3 (3.42). However, when used at a ratio of 1:5:1:5, $n$-hexane/ethyl acetate/methanol/water yielded $K$ values for all three compounds that allowed their separation. Therefore, the latter two-phase solvent system was adopted for further HSCCC separation. As shown in Figure 2B, $240 \mathrm{mg}$ of MBE were separated and purified in one step by HSCCC under the optimal separation conditions, and the three peaks were well resolved in a single run. The separation time was $\sim 210 \mathrm{~min}$ for each run. The three compounds were eluted with good resolution and in the order of their increasing $K$ values. 
Thus, three fractions were collected, with compound 1 (18.3 mg) obtained from peak 1, compound 2 (20.5 $\mathrm{mg}$ ) obtained from peak $\mathbf{2}$, and compound 3 (28.4 $\mathrm{mg}$ ) obtained from peak 3 . The purity of each of the three target compounds was $>92 \%$ as determined by HPLC (Figure 3A-D).

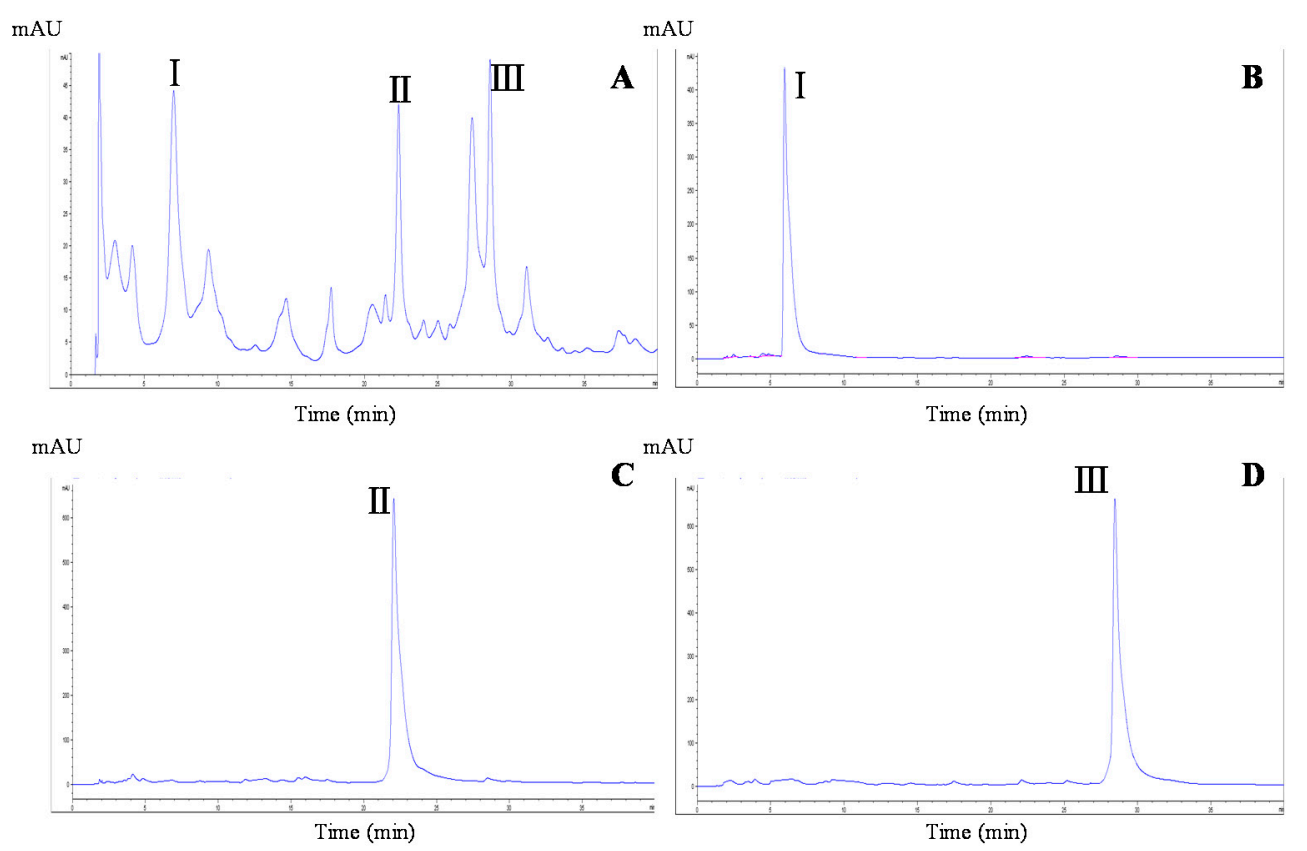

Figure 3. HPLC chromatograms of the MBE and HSCCC peak fractions. (A) MBE; (B) peak 1 in Figure 2; (C) peak 2 in Figure 2; (D) peak 3 in Figure 2.

Table 1. The partition coefficients ( $K$ values) of compounds 1-3 in the two-phase solvent systems of $n$-hexane/ethyl acetate/methanol/water as determined by HPLC.

\begin{tabular}{ccccc}
\hline \multirow{2}{*}{ No. } & Ratio (v/v) & \multicolumn{3}{c}{ K values } \\
\cline { 3 - 5 } & & I & II & III \\
\hline 1 & $1: 1: 1: 1$ & 0.09 & 0.23 & 0.32 \\
2 & $1: 2: 1: 2$ & 0.21 & 0.45 & 0.57 \\
3 & $1: 5: 1: 2$ & 0.73 & 1.03 & 3.42 \\
4 & $1: 5: 1: 5$ & 0.65 & 1.21 & 1.86 \\
\hline
\end{tabular}

\subsection{Structural Identification of Compounds}

The structure of the isolated compounds was identified by ESI-MS, ${ }^{1} \mathrm{H}-\mathrm{NMR}$, and ${ }^{13} \mathrm{C}$ NMR (Figure 1).

Compound 1: colorless solid, $\mathrm{C}_{16} \mathrm{H}_{18} \mathrm{O}_{9}$; ESI-MS: $m / z 377[\mathrm{M}+\mathrm{Na}]^{+} ;{ }^{1} \mathrm{H}$ NMR $\left(600 \mathrm{MHz}, \mathrm{CD}_{3} \mathrm{OD}\right)$ $\delta_{\mathrm{H}}: 7.55\left(1 \mathrm{H}, \mathrm{d}, J=15.6 \mathrm{~Hz}, \mathrm{H}-7^{\prime}\right), 7.05\left(1 \mathrm{H}, \mathrm{d}, J=2.0 \mathrm{~Hz}, \mathrm{H}-2^{\prime}\right), 6.96\left(1 \mathrm{H}, \mathrm{dd}, J=7.8,1.8 \mathrm{~Hz}, \mathrm{H}-6^{\prime}\right)$, $6.78\left(1 \mathrm{H}, \mathrm{d}, J=7.8 \mathrm{~Hz}, \mathrm{H}-5^{\prime}\right), 6.26\left(1 \mathrm{H}, \mathrm{d}, J=15.6 \mathrm{~Hz}, \mathrm{H}-8^{\prime}\right), 5.33(1 \mathrm{H}, \mathrm{ddd}, J=9.0,9.0,4.5 \mathrm{~Hz}, \mathrm{H}-5)$, $4.17(1 \mathrm{H}, \mathrm{ddd}, J=5.0,3.5,3.5 \mathrm{~Hz}, \mathrm{H}-3), 3.73(1 \mathrm{H}, \mathrm{dd}, J=8.5,3.0 \mathrm{~Hz}, \mathrm{H}-4), ~ 2.03-2.21(4 \mathrm{H}, \mathrm{m}, \mathrm{H}-2$, 6); ${ }^{13} \mathrm{C}$ NMR (150 MHz, CD $\left.3 \mathrm{OD}\right) \delta_{\mathrm{C}}: 177.3(\mathrm{C}-7), 168.9\left(\mathrm{C}-9^{\prime}\right), 149.7\left(\mathrm{C}-4^{\prime}\right), 147.3\left(\mathrm{C}-7^{\prime}\right), 146.9\left(\mathrm{C}-3^{\prime}\right)$, $127.9\left(\mathrm{C}-1^{\prime}\right), 123.2\left(\mathrm{C}-6^{\prime}\right), 116.7\left(\mathrm{C}-5^{\prime}\right), 115.4\left(\mathrm{C}-2^{\prime}, 8^{\prime}\right), 76.3(\mathrm{C}-1), 73.6(\mathrm{C}-4), 72.1(\mathrm{C}-5), 71.4$ (C-3), 38.9 (C-6), 38.3 (C-2). Comparing the above data with the literature data [16], compound 1 was identified as chlorogenic acid.

Compound 2: yellow amorphous powder, $\mathrm{C}_{21} \mathrm{H}_{20} \mathrm{O}_{12}$; ESI-MS: $m / z 487[\mathrm{M}+\mathrm{Na}]^{+} ;{ }^{1} \mathrm{H}$ NMR $\left(600 \mathrm{MHz}, \mathrm{DMSO}-d_{6}\right)$ spectrum showed signals at $\delta_{\mathrm{H}} 12.63(1 \mathrm{H}, \mathrm{s}, \mathrm{OH}-5), 6.20(1 \mathrm{H}, \mathrm{d}, J=2.4 \mathrm{~Hz}, \mathrm{H}-6)$, $6.40(1 \mathrm{H}, J=2.4 \mathrm{~Hz}, \mathrm{H}-8), 6.84\left(1 \mathrm{H}, \mathrm{d}, J=9.0 \mathrm{~Hz}, \mathrm{H}-5^{\prime}\right)$, and $7.58\left(2 \mathrm{H}, \mathrm{m}, \mathrm{H}-6^{\prime}, 2^{\prime}\right)$ ascribed to quercetin moiety. The anomeric proton signal of glucoside residue was observed at $\delta_{\mathrm{H}} 5.46(1 \mathrm{H}, \mathrm{d}, J=7.8 \mathrm{~Hz})$; ${ }^{13} \mathrm{C}$ NMR $\left(150 \mathrm{MHz}\right.$, DMSO- $d_{6}$ ) exhibited the presence of 21 signals, including 15 carbon resonances 
for flavonoid aglycone at $\delta_{\mathrm{C}} 177.5$ (C-4), 164.1 (C-7), 161.2 (C-5), 156.3 (C-2), 156.2 (C-9), 148.5 (C-4'), $144.8\left(\mathrm{C}-3^{\prime}\right), 133.5(\mathrm{C}-3), 121.6\left(\mathrm{C}-1^{\prime}\right), 121.1\left(\mathrm{C}-6^{\prime}\right), 116.2\left(\mathrm{C}-5^{\prime}\right), 115.2\left(\mathrm{C}-2^{\prime}\right), 103.0(\mathrm{C}-10), 98.7(\mathrm{C}-6)$, and $93.5(\mathrm{C}-8)$, and sugar moiety at $\delta_{\mathrm{C}} 60.2,69.9,74.1,76.5,77.6$, and 100.9. These ESI-MS, ${ }^{1} \mathrm{H}$, and ${ }^{13} \mathrm{C}$ NMR data were similar to those in a previous report [17]. Therefore, compound 2 was identified as quercetin-3-O- $\beta$-D-glucopyranoside.

Compound 3: yellow amorphous powder, $\mathrm{C}_{22} \mathrm{H}_{22} \mathrm{O}_{12}$; ESI-MS $m / z 501[\mathrm{M}+\mathrm{H}]^{+},{ }^{1} \mathrm{H}$ NMR $\left(\mathrm{CD}_{3} \mathrm{OD}, 600 \mathrm{MHz}\right)$ spectrum displayed flavonoid proton signals at $\delta_{\mathrm{H}} 7.92\left(1 \mathrm{H}, \mathrm{d}, J=1.8 \mathrm{~Hz}, \mathrm{H}-2^{\prime}\right)$, $7.44\left(1 \mathrm{H}, \mathrm{dd}, J=8.4,1.8 \mathrm{~Hz}, \mathrm{H}-6^{\prime}\right), 6.87\left(1 \mathrm{H}, \mathrm{d}, J=8.4 \mathrm{~Hz}, \mathrm{H}-5^{\prime}\right), 6.17(1 \mathrm{H}, \mathrm{br} \mathrm{s}, \mathrm{H}-8)$, and $5.97(1 \mathrm{H}, \mathrm{br}$ s, H-6), an anomeric proton at $\delta_{\mathrm{H}} 5.57\left(1 \mathrm{H}, \mathrm{d}, J=7.5 \mathrm{~Hz}, \mathrm{H}-1^{\prime \prime}\right)$, and a methoxyl group at $3.82(3 \mathrm{H}, \mathrm{s}$, $4^{\prime}$-OMe); ${ }^{13} \mathrm{C}$ NMR $\left(150 \mathrm{MHz}, \mathrm{DMSO}-d_{6}\right)$ spectrum flavonoid carbon resonances at $\delta_{\mathrm{C}} 177.5(\mathrm{C}-4), 164.1$ (C-7), 161.2 (C-5), 156.3 (C-2), 156.2 (C-9), 149.4 (C-4'), 146.9 (C-3'), 133.0 (C-3), 122.0 (C-1'), $121.1\left(\mathrm{C}-6^{\prime}\right)$, $115.2\left(\mathrm{C}-5^{\prime}\right), 113.5\left(\mathrm{C}-2^{\prime}\right), 104.0$ (C-10), 98.7 (C-6), and 93.5 (C-8). Glucoside residue carbon signals were observed at $\delta_{C} 60.1,69.8,74.1,76.5,77.6$, and 100.8. These data were in good agreement with the reported compound 3 [18], isorhamnetin-3-O- $\beta$-D-glucopyranoside.

\subsection{Antioxidant Activities of the Target-Isolated Compounds}

Phenolic compounds are widely distributed in plants, vegetables, and fruits, and have been recognized as powerful in vitro antioxidants due to their ability to scavenge free radicals via donated hydrogen atoms or electrons $[19,20]$. Since the total antioxidant capacity of a compound cannot be determined in a single assay, we used a combination of free-radical scavenging methods to evaluate the antioxidant potential of compounds 1-3.

$\mathrm{DPPH}$ is a stable organic nitrogen radical that has been used extensively as a basic screening method to test the antioxidant abilities of natural resources according to their hydrogen-donating ability [21]. The assay was conducted in methanol, and the results are expressed as $\mathrm{IC}_{50}$ values (Table 2). In the case of the three isolated compounds, the activity of compound 2 against DPPH was the highest ( $\mathrm{IC}_{50}$ of $\left.9.64 \mu \mathrm{g} / \mathrm{mL}\right)$, followed by compound $3(18.45 \mu \mathrm{g} / \mathrm{mL})$ and compound $1(36.51 \mu \mathrm{g} / \mathrm{mL})$. The IC 50 of ascorbic acid, a free-radical scavenger used as the reference control in this study, was $10.42 \mu \mathrm{g} / \mathrm{mL}$. The free-radical scavenging capacity of flavonoids (compounds $\mathbf{2}$ and $\mathbf{3}$ ) is dependent on the catechol moiety in ring B [22]. Compound 2 contains one more hydroxyl group than compound 3, and thus has a greater ability to quench DPPH radicals. Compound $\mathbf{1}$ possesses only one hydroxycinnamic acid moiety, and is thus a weaker scavenger compared with compounds 2 and $\mathbf{3}$.

Large quantities of superoxide radicals are generated in the body by a variety of metabolic and physiological processes [23]. Superoxide radicals are the precursors of singlet oxygen and hydroxyl radicals, both of which may be very harmful to cellular components [24]. Therefore, we examined the superoxide radical scavenging ability of the isolated compounds in a phenazine methosulfate-nicotinamide adenine dinucleotide superoxide-generating system using gallic acid as the control. As shown in Table 2, compound 2 exhibited significantly stronger superoxide radical scavenging ability than those of compounds $\mathbf{1}$ and $\mathbf{3}$, based on the $\mathrm{IC}_{50}$ values. The structure-antioxidant relationship was similar to that determined using DPPH. The relative order of the three isolated compounds and gallic acid with respect to their superoxide radical scavenging capacities was compound $\mathbf{2}>$ gallic acid $>$ compound $\mathbf{1}>$ compound $\mathbf{3}$.

Table 2. Free-radical scavenging activities of isolated compounds from M. bealei leaves.

\begin{tabular}{ccc}
\hline Samples & DPPH $\left(\mathrm{IC}_{\mathbf{5 0}}, \boldsymbol{\mu \mathrm { g } / \mathrm { mL } )}\right.$ & ${\boldsymbol{\bullet \mathbf { O } _ { 2 }}}^{-}\left(\mathbf{I C}_{\mathbf{5 0}}, \boldsymbol{\mu g} / \mathrm{mL}\right)$ \\
\hline Compound 1 & $18.45 \pm 2.34^{\mathrm{c}}$ & $134.15 \pm 11.49^{\mathrm{c}}$ \\
Compound 2 & $9.64 \pm 0.52^{\mathrm{a}}$ & $85.54 \pm 5.32^{\mathrm{a}}$ \\
Compound 3 & $36.51 \pm 4.16^{\mathrm{d}}$ & $206.86 \pm 20.76^{\mathrm{d}}$ \\
Ascorbic acid & $10.42 \pm 0.72^{\mathrm{b}}$ & - \\
Gallic acid & - & $96.85 \pm 4.39^{\mathrm{b}}$
\end{tabular}

Each value is the mean \pm SD of triplicate measurements. Values with different letters differ significantly $(p<0.05)$. 


\subsection{Cytoprotective Abilities and Inhibition of Lipid Peroxidation in $\mathrm{H}_{2} \mathrm{O}_{2}$-Treated $\mathrm{RAW} 264.7$ Cells}

The in vitro chemical assays employed in this study do not reflect the physiological conditions of cells. $\mathrm{H}_{2} \mathrm{O}_{2}$, a form of reactive oxygen species (ROS), can penetrate cell membranes and cause oxidative cellular damage [25]. Its suppression may prevent $\mathrm{H}_{2} \mathrm{O}_{2}$-mediated oxidative stress in cells [26]. Therefore, we examined the ability of compounds $\mathbf{1}$ to 3 to scavenge free radicals in a cellular environment by assaying their protection against $\mathrm{H}_{2} \mathrm{O}_{2}$-induced oxidative damage in the macrophage cell line RAW264.7. An initial determination of the cytotoxic dose of $\mathrm{H}_{2} \mathrm{O}_{2}$ in RAW 264.7 cells showed moderate cell injury induced by $200 \mu \mathrm{M}$ of $\mathrm{H}_{2} \mathrm{O}_{2}$. Therefore, RAW264.7 cells were first treated for $0.5 \mathrm{~h}$ with non-toxic concentrations (data not shown) of compounds 1-3, and then for an additional $12 \mathrm{~h}$ with $\mathrm{H}_{2} \mathrm{O}_{2}$. As shown in Figure $4 \mathrm{~A}$, compared with the vehicle-treated group, there was a significant decrease in the viability of cells exposed to $\mathrm{H}_{2} \mathrm{O}_{2}$. However, in cells pretreated with the three compounds, viability was significantly higher than that in the vehicle group, and the highest values corresponded to compound $\mathbf{2}$, followed by compound $\mathbf{1}$ and $\mathbf{3}$.

A

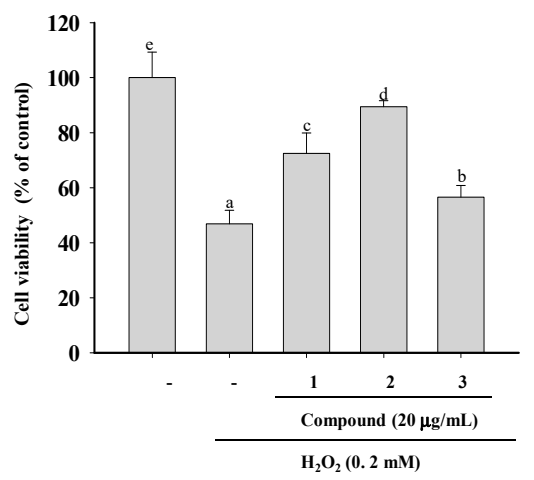

C

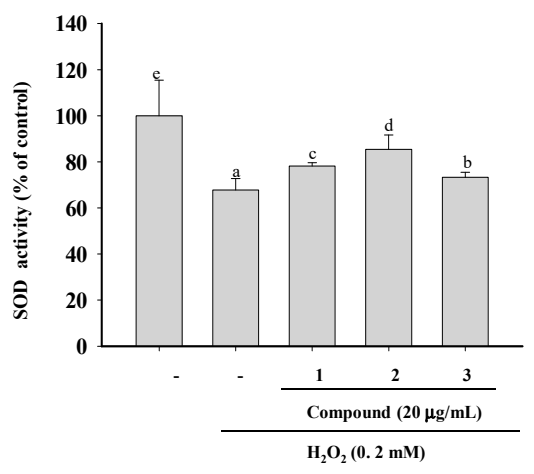

B

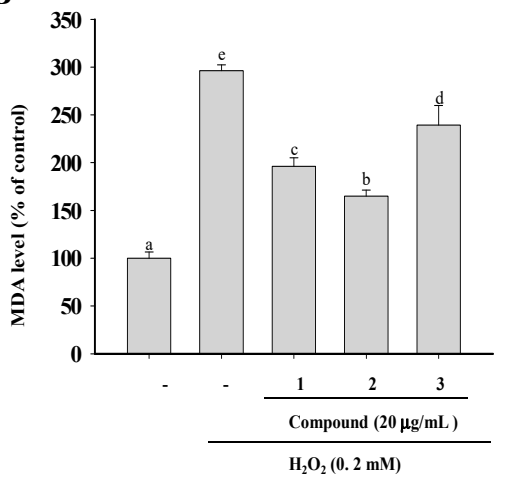

D

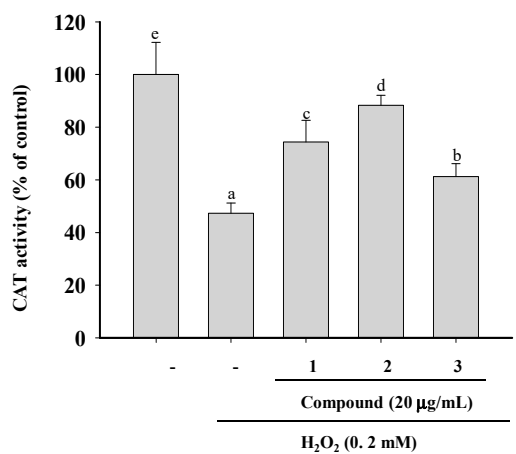

Figure 4. Cytoprotective activities of compounds 1-3. (A) RAW 264.7 macrophages were exposed to the test compounds for $0.5 \mathrm{~h}$ and then to $200 \mu \mathrm{M}$ of $\mathrm{H}_{2} \mathrm{O}_{2}$ for $6 \mathrm{~h}$. Cell viability was measured using the 1-(4,5-dimethylthiazol-2-yl)-3,5-diphenylformazan (MTT) assay. (B) The malondialdehyde (MDA) content and activities of the antioxidant enzymes superoxide dismutase (SOD) (C) and catalase (CAT) (D) were determined using commercial kits according to the manufacturers' instructions. The data are presented as means $\pm \mathrm{SD}(\mathrm{n}=3)$. Values with the same superscript letters are not significantly different from each other at $p<0.05$.

The presence of unsaturated phospholipids in cell membranes render them vulnerable to free radicals, which initiate a chain reaction that results in the accumulation of end products such as malondialdehyde (MDA) and unsaturated aldehydes [27,28]. To evaluate the ability of compounds 1-3 to protect cells against macromolecular damage following $\mathrm{H}_{2} \mathrm{O}_{2}$ exposure, we followed the formation of MDA as a marker of oxidative damage. As shown in Figure 4B, treatment with $\mathrm{H}_{2} \mathrm{O}_{2}$ enhanced lipid peroxidation and MDA levels significantly (296.19\%) compared with the control group, 
demonstrating that cellular polyunsaturated fatty acids underwent $\mathrm{H}_{2} \mathrm{O}_{2}$-mediated oxidative damage. However, the preincubation of the cells with compounds 1-3 significantly lowered MDA levels to $196.23 \%, 164.91 \%$, and $239.31 \%$, respectively. These results again demonstrate the greater potency of compound 2 in the scavenging of ROS and the inhibition of $\mathrm{H}_{2} \mathrm{O}_{2}$-induced lipid peroxidation.

Generally, cells respond to oxidative stress with adaptive changes designed to prevent cellular damage and increase survival [29]. Among the components of the cellular defense system against oxidative stress are the antioxidant enzymes superoxide dismutase (SOD) and catalase (CAT), which provide first-line cellular protection against excess amounts of free radicals [30,31]. The treatment of RAW264.7 cells with $200 \mu \mathrm{M}$ of $\mathrm{H}_{2} \mathrm{O}_{2}$ for $12 \mathrm{~h}$ significantly decreased the activities of SOD and CAT by $67.76 \%$ and $42.29 \%$, respectively, indicating impaired antioxidant defenses (Figure 4C,D). However, preincubation with compounds 1-3 significantly attenuated the $\mathrm{H}_{2} \mathrm{O}_{2}$-induced changes in SOD and CAT.

\section{Materials and Methods}

\subsection{Material and Reagents}

M. bealei leaves were purchased from Guizhou Province (China) in 2013, and the voucher specimen (MBL-2013) was deposited in the Jiangsu Collaborative Innovation Center Of Regional Modern Agriculture and Environmental Protection. The crude extract and each fraction were from $M$. bealei leaves were prepared as described previously [11]. Since the ethyl acetate fraction of $M$. bealei leaf extract (MBE) was more efficacious than the other fractions for scavenging free radicals, the MBE fraction was considered for ongoing research. 1,1-Diphenyl-2-picryl-hydrazyl (DPPH), phenazine methosulfate (PMS), nitro blue tetrazolium (NBT), $\beta$-nicotinamide adenine dinucleotide (NADH), and 1-(4,5-dimethylthiazol-2-yl)-3,5-diphenylformazan (MTT) were purchased from Sigma (St. Louis, MO, USA). Fetal bovine serum (FBS) was obtained from Corning (Mediatech, Manassas, VA, USA). The Roswell Park Memorial Institute (RPMI) 1640 medium was purchased from Gibco BRL (Life Technologies, China). Penicillin-streptomycin solution was acquired from Gibco BRL (Grand Island, NY, USA). Phosphate-buffered saline (PBS, pH 7.4) tablets were obtained from Amresco (Solon, $\mathrm{OH}, \mathrm{USA})$. Assay kits for catalase (CAT), malondialdehyde (MDA), and superoxide dismutase (SOD) were purchased from the Institute of Nanjing Jiancheng Bioengineering (Nanjing, China). The organic solvents used for fraction and HSCCC separation were purchased from Sinopharm Chemical Reagent Co., Ltd. (Shanghai, China). All the aqueous solutions were prepared with deionized water produced by Millipore Direct-Q3 Water Purification system (Bredford, MA, USA).

\subsection{Apparatus}

The preparative HSCCC instrument employed in this study was a Tauto TBE-300B (Shanghai, China). It was equipped with three polytetrafluoroethylene coil columns, a Tauto TBP-5002 constant-flow pump, a QuikSep UV-50 UV detector (H\&E Factory, Beijing, China), and a DBS-100 mode fraction collector (Shanghai Huxi Instruments Factory, Shanghai, China). The Agilent 1260 system (Santa Clara, CA, USA) was employed for HPLC-UV analysis. ESI-MS spectra were obtained with an LTQ-Orbitrap XL spectrometer (Thermo Fisher Scientific, Bremen, Germany). ${ }^{1} \mathrm{H}$ NMR and ${ }^{13} \mathrm{C}$ NMR data were recorded using a Bruker Avance 600 NMR spectrometer (Fällanden, Switzerland).

\subsection{Measurement of the Partition Coefficient (K)}

The procedure used to determine $K$ was as follows: approximately $5 \mathrm{mg}$ of MBE was dropped into a test tube, and $2 \mathrm{~mL}$ of equilibrated two-phase solvent was added to the tube. The glass tube was shaken vigorously for $2 \mathrm{~min}$ to separate the upper and lower phases completely. Then, one milliliter of each phase was dried under $\mathrm{N}_{2}$ at $40{ }^{\circ} \mathrm{C}$ and re-dissolved in acetonitrile for HPLC. The $K$ value for each target compound was calculated as the ratio of each peak in the upper and lower phases. 


\subsection{HSCCC Separation}

A two-phase solvent system consisting of $n$-hexane/ethyl acetate/methanol/water (1:5:1:5, v/v/v/v) was selected for HSCCC separation. Each solvent was added into a separate funnel and shaken vigorously at room temperature. The two phases were separated and degassed by sonication before use. The coil column was first entirely filled with the upper phase by a constant flow pump; subsequently, the lower mobile phase was then pumped into the inlet of the column at a flow rate of $2 \mathrm{~mL} / \mathrm{min}$, after which the apparatus was rotated at a revolution speed of $900 \mathrm{rpm}$ in tail-head elution mode. After a hydrodynamic equilibrium was established, an approximately 10-mL sample solution was injected into the injection valve. The peak fractions were manually collected according to the chromatogram with a UV detector at $254 \mathrm{~nm}$ and then evaporated under a vacuum rotary evaporator.

\subsection{In Vitro Antioxidant Activity}

\subsubsection{DPPH Free-Radical Scavenging Assay}

The antioxidant potency of the different samples was determined based on the method [32]. Briefly, a methanol solution ( $100 \mu \mathrm{L}$ of the sample at various concentrations) was mixed with $100 \mu \mathrm{L}$ of methanol solution of DPPH $(0.2 \mathrm{mM})$. After reacting for $30 \mathrm{~min}$ in the dark at room temperature, the optical density was read at $517 \mathrm{~nm}$ in a spectrophotometer. The concentrations of test samples at which there is a $50 \%$ fall in the absorbance of $\mathrm{DPPH}$ values $\left(\mathrm{IC}_{50}\right)$ were calculated by a dose-response curve using Microsoft Office Excel 2010 (Microsoft Corp., Redmond, WA, USA).

\subsubsection{DPPH-HPLC Experiment}

The DPPH-HPLC experiment was carried out according to the previous literature with slight modifications [33]. Briefly, a volume of $200 \mu \mathrm{L}$ of $5 \mathrm{mg} / \mathrm{mL}$ MBE was mixed with DPPH solution $(0.2 \mathrm{mM}$ in acetonitrile). After passing through a $0.45-\mu \mathrm{m}$ syringe filter, the reaction mixtures were analyzed by HPLC in comparison with a blank and control. The mixtures were separated and analyzed by a reversed-phase ZORBAX ODS ( $150 \mathrm{~mm} \times 4.6 \mathrm{~mm}$ i.d., $5 \mu \mathrm{m}$, Milford, MA, USA) column. The mobile phase consisted of $\mathrm{A}(0.4 \%$ acetic acid in water) and $\mathrm{B}$ (acetonitrile), which was programmed as follows: 0-40 $\mathrm{min}, 10-25 \% \mathrm{~B}$. The flow rate was $1 \mathrm{~mL} / \mathrm{min}$, while the ambient temperature was controlled at $30^{\circ} \mathrm{C}$, and $254 \mathrm{~nm}$ was selected as the detection wavelength.

\subsubsection{Superoxide Radical Scavenging Assay}

The superoxide radical scavenging activity of different samples was measured by the reduction of NBT according to the previously reported method with minor modifications [34]. The reaction mixture consisted of $100 \mu \mathrm{L}$ of each sample, $1 \mathrm{~mL}$ of $0.1 \mathrm{M}$ phosphate buffer (pH 7.4), $100 \mu \mathrm{L}$ of NBT $(150 \mu \mathrm{M})$, $100 \mu \mathrm{L}$ of NADH $(468 \mu \mathrm{M})$, and $20 \mu \mathrm{L}$ of PMS $(60 \mu \mathrm{M})$. After 5 min of reaction at ambient temperature, the absorbance of the aqueous solution was determined at $560 \mathrm{~nm}$.

\subsubsection{Cell Line and Cell Culture}

The RAW264.7 mouse macrophage cell line was provided by the American Type Culture Collection (ATCC) (Manassas, VA, USA). RAW264.7 was plated into T-75 flasks and grown in RPMI 1640 medium containing $10 \%$ heat-inactivated FBS and $1 \%$ antibiotic solution (penicillin/streptomycin) at $37^{\circ} \mathrm{C}$ in a humidified atmosphere of $95 \%$ air and $5 \% \mathrm{CO}_{2}\left(95 \%\right.$ air, $\left.5 \% \mathrm{CO}_{2}\right)$.

\subsubsection{Cell Viability Assay}

Cytotoxicity was investigated by MTT assay as previously described [35]. Prior to the experiment, cells were seeded into 96-well plates at a density of $1 \times 10^{5}$ cells/well for $18 \mathrm{~h}$. Then, the culture medium was replaced with fresh medium along with the test compounds at various concentrations for $1 \mathrm{~h}$ and exposed to $0.2 \mathrm{mM}$ of $\mathrm{H}_{2} \mathrm{O}_{2}$ for an additional $12 \mathrm{~h}$. Following this, the medium was carefully 
removed, and $10 \mu \mathrm{L}$ of MTT solution ( $5 \mathrm{mg} / \mathrm{mL}$ in PBS) and $90 \mu \mathrm{L}$ of FBS-free medium were added to each well and incubated at $37^{\circ} \mathrm{C}$ for $4 \mathrm{~h}$. The formazan crystals were solubilized in MTT stop buffer overnight. The absorbance was measured at $550 \mathrm{~nm}$ using a microplate multi-well reader (Tecan, Zurich, Switzerland). Cell viability was expressed as a percentage of control cells.

\subsubsection{Measurement of Lipid Peroxidation and CAT and SOD Activities}

A total of $2 \times 10^{6}$ cells were seeded in six-well plates for $16 \mathrm{~h}$. Then, the culture medium was replaced with fresh medium and treated as described in Section 3.5.5. After treatment, cells were washed twice with ice-cold PBS and dissociated by cell lysis buffer. The supernatant was collected for measuring the MDA levels and activities CAT and SOD using assay kits according to the protocol of the manufacturer. The protein content was measured by with a MicroBCA protein assay kit (CWBIO, Beijing, China) using bovine serum albumin as the standard.

\subsection{Data Analysis}

All analyses were performed using SPSS 19.0 package (SPSS Inc., Chicago, IL, USA) for Windows 7. Values shown represent the mean \pm standard derivation (SD). Differences among samples were compared using a Duncan's multiple range test, and $p$-values less than $5 \%$ were considered to be statistically different.

\section{Conclusions}

Target-guided isolation way was set up to isolate three main antioxidants from $M$. bealei leaves using HSCCC. The described method also has broader applicability in the screening and preparation of other free radical scavengers present in crude plant extracts. The results obtained in this study clearly demonstrate the potent free-radical scavenging activities of compounds 1-3 and their ability to reduce oxidative stress in $\mathrm{H}_{2} \mathrm{O}_{2}$-treated RAW264.7 cells by decreasing intracellular MDA levels and increasing SOD and CAT activities. In all assays, a consistently similar trend was established with respect to the antioxidant activities of the three compounds, which were ranked as follows: compound $\mathbf{2}>$ compound $\mathbf{1}>$ compound $\mathbf{3}$. The identification of these antioxidants should stimulate further research aimed at identifying other important molecules in $M$. bealei leaves and their applications in the food and pharmaceutical industries.

Author Contributions: W.H. performed the experiments. X.W. and J.Z. conceived and designed the experiments and analyzed the data. T.S. and X.W. wrote the paper. All the authors helped prepare the paper and approved the final version.

Funding: This research was funded by National Natural Science Foundation of China (31600281), Natural Science Foundation of Jiangsu Province (BK20171269), and Top-notch Academic Programs Project of Jiangsu Higher Education Institutions (PPZY2015A018).

Acknowledgments: We thank Fu Li (Chengdu Institute of Biology, Chinese Academy of Sciences) for helpful discussions on NMR result.

Conflicts of Interest: The authors declare that there are no conflicts of interest.

\section{References}

1. Singh, S.; Brocker, C.; Koppaka, V.; Chen, Y.; Jackson, B.C.; Matsumoto, A.; Thompson, D.C.; Vasiliou, V. Aldehyde dehydrogenases in cellular responses to oxidative/electrophilic stress. Free Radic. Biol. Med. 2013, 56, 89-101. [CrossRef] [PubMed]

2. Kehrer, J.P.; Lars-Oliver, K. Free radicals and related reactive species as mediators of tissue injury and disease: Implications for Health. Crit. Rev. Toxicol. 2015, 45, 765-798. [CrossRef] [PubMed]

3. Rahal, A.; Kumar, A.; Singh, V.; Yadav, B.; Tiwari, R.; Chakraborty, S.; Dhama, K. Oxidative stress, prooxidants, and antioxidants: The interplay. Biomed Res. Int. 2014, 2014, 761264. [CrossRef] [PubMed]

4. Nile, S.H.; Park, S.W. Edible berries: Bioactive components and their effect on human health. Nutrition 2014, 30, 134-144. [CrossRef] [PubMed] 
5. Si, C.L.; Shen, T.; Jiang, Y.Y.; Wu, L.; Yu, G.J.; Ren, X.D.; Xu, G.H.; Hu, W.C. Antioxidant properties and neuroprotective effects of isocampneoside II on hydrogen peroxide-induced oxidative injury in PC12 cells. Food Chem. Toxicol. 2013, 59, 145-152. [CrossRef]

6. Barreca, D.; Laganà, G.; Leuzzi, U.; Smeriglio, A.; Trombetta, D.; Bellocco, E. Evaluation of the nutraceutical, antioxidant and cytoprotective properties of ripe pistachio (Pistacia vera L., variety Bronte) hulls. Food Chem. 2016, 196, 493-502. [CrossRef]

7. Dobravalskytè, D.; Venskutonis, P.R.; Talou, T. Antioxidant properties and essential oil composition of Calamintha grandiflora L. Food Chem. 2012, 135, 1539-1546. [CrossRef]

8. Jin, L.; Li, X.B.; Tian, D.Q.; Fang, X.P.; Yu, Y.M.; Zhu, H.Q.; Ge, Y.Y.; Ma, G.Y.; Wang, W.Y.; Xiao, W.F. Antioxidant properties and color parameters of herbal teas in China. Ind. Crops Prod. 2016, 87, 198-209. [CrossRef]

9. He, J.M.; Mu, Q. The medicinal uses of the genus Mahonia in traditional Chinese medicine: An ethnopharmacological, phytochemical and pharmacological review. J. Ethnopharmacol. 2015, 175, 668-683. [CrossRef] [PubMed]

10. Wu, L.; Wang, G.; Shen, T.; You, L.; Hu, W.; Si, C.L. Optimizing conditions for antioxidant phenolic compound extraction from Mahonia bealei (Fort.) Carr. leaves using a response surface methodology. Hortic. Environ. Biotechnol. 2017, 58,1-10. [CrossRef]

11. Hu, W.; Wu, L.; Qiang, Q.; Ji, L.; Wang, X.; Luo, H.; Wu, H.; Jiang, Y.; Wang, G.; Shen, T. The dichloromethane fraction from Mahonia bealei (Fort.) Carr. leaves exerts an anti-inflammatory effect both in vitro and in vivo. J. Ethnopharmacol. 2016, 188, 134-143. [CrossRef] [PubMed]

12. Zhang, S.L.; Li, H.; He, X.; Zhang, R.Q.; Sun, Y.H.; Zhang, C.F.; Wang, C.Z.; Yuan, C.S. Alkaloids from Mahonia bealei posses anti- $\mathrm{H}^{+} / \mathrm{K}^{+}$-ATPase and anti-gastrin effects on pyloric ligation-induced gastric ulcer in rats. Phytomedicine 2014, 21, 1356-1363. [CrossRef] [PubMed]

13. Pedan, V.; Fischer, N.; Rohn, S. An online NP-HPLC-DPPH method for the determination of the antioxidant activity of condensed polyphenols in cocoa. Food Res. Int. 2016, 89, 890-900. [CrossRef]

14. Zhao, Y.; Wang, Y.; Jiang, Z.T.; Li, R. Screening and evaluation of active compounds in polyphenol mixtures by HPLC coupled with chemical methodology and its application. Food Chem. 2017, 227, 187-193. [CrossRef]

15. Gu, D.Y.; Yang, Y.; Zhong, J.; Aisa, H.A.; Zhang, T.Y. High-speed counter-current chromatography combined with column chromatography for isolation of methyllycaconitine from Delphinium pseudocyanthum. Chromatographia 2007, 66, 949-951. [CrossRef]

16. Jin, U.H.; Lee, J.Y.; Kang, S.K.; Kim, J.K.; Park, W.H.; Kim, J.G.; Moon, S.K.; Kim, C.H. A phenolic compound, 5-caffeoylquinic acid (chlorogenic acid), is a new type and strong matrix metalloproteinase-9 inhibitor: Isolation and identification from methanol extract of Euonymus alatus. Life Sci. 2005, 77, 2760-2769. [CrossRef] [PubMed]

17. Shokoohinia, Y.; Rashidi, M.; Hosseinzadeh, L.; Jelodarian, Z. Quercetin-3-O- $\beta$-D-glucopyranoside, a dietary flavonoid, protects $\mathrm{PC} 12$ cells from $\mathrm{H}_{2} \mathrm{O}_{2}$-induced cytotoxicity through inhibition of reactive oxygen species. Food Chem. 2015, 167, 162-167. [CrossRef] [PubMed]

18. Wang, D.M.; Pu, W.J.; Wang, Y.H.; Zhang, Y.J.; Wang, S.S. A new isorhamnetin glycoside and other phenolic compounds from Callianthemum taipaicum. Molecules 2012, 17, 4595-4603. [CrossRef]

19. Hua, Z.; Rong, T. Dietary polyphenols, oxidative stress and antioxidant and anti-inflammatory effects. Curr. Opin. Food Sci. 2016, 8, 33-42.

20. Losada-Barreiro, S.; Bravo-Díaz, C. Free radicals and polyphenols: The redox chemistry of neurodegenerative diseases. Eur. J. Med. Chem. 2017, 133, 379-402. [CrossRef]

21. Wojtunik, K.A.; Ciesla, L.M.; Waksmundzkahajnos, M. Model studies on the antioxidant activity of common terpenoid constituents of essential oils by means of the 2,2-diphenyl-1-picrylhydrazyl method. J. Agric. Food Chem. 2014, 62, 9088-9094. [CrossRef]

22. Wen, L.; Jiang, Y.; Yang, J.; Zhao, Y.; Tian, M.; Yang, B. Structure, bioactivity, and synthesis of methylated flavonoids. Ann. N. Y. Acad. Sci. 2017, 1398, 120-129. [CrossRef] [PubMed]

23. Paudel, B.; Bhattarai, H.D.; Koh, H.Y.; Lee, S.G.; Han, S.J.; Lee, H.K.; Oh, H.; Shin, H.W.; Yim, J.H. Ramalin, a novel nontoxic antioxidant compound from the Antarctic lichen Ramalina terebrata. Phytomedicine 2011, 18, 1285-1290. [CrossRef]

24. Li, K.; Xing, R.; Liu, S.; Qin, Y.; Li, B.; Wang, X.; Li, P. Separation and scavenging superoxide radical activity of chitooligomers with degree of polymerization 6-16. Int. J. Biol. Macromol. 2012, 51, 826-830. [CrossRef] 
25. Zhang, J.; Stanley, R.A.; Adaim, A.; Melton, L.D.; Skinner, M.A. Free radical scavenging and cytoprotective activities of phenolic antioxidants. Mol. Nutr. Food Res. 2010, 50, 996-1005. [CrossRef] [PubMed]

26. Weinstain, R.; Savariar, E.N.; Felsen, C.N.; Tsien, R.Y. In vivo targeting of hydrogen peroxide by activatable cell-penetrating peptides. J. Am. Chem. Soc. 2014, 136, 874-877. [CrossRef] [PubMed]

27. Cobb, C.A.; Cole, M.P. Oxidative and nitrative stress in neurodegeneration. Neurobiol. Dis. 2015, 84, 4-21. [CrossRef]

28. Naudí, A.; Jové, M.; Ayala, V.; Cabré, R.; Porterootín, M.; Pamplona, R. Non-enzymatic modification of aminophospholipids by carbonyl-amine reactions. Int. J. Mol. Sci. 2013, 14, 3285-3313. [CrossRef]

29. Schieber, M.; Chandel, N.S. ROS function in redox signaling and oxidative stress. Curr. Biol. 2014, 24, R453-R462. [CrossRef]

30. Li, L.; Du, J.; Lian, Y.; Zhang, Y.; Li, X.; Liu, Y.; Zou, L.; Wu, T. Protective effects of coenzyme Q10 against hydrogen peroxide-induced oxidative stress in PC12 Cell: The role of Nrf2 and antioxidant enzymes. Cell. Mol. Neurobiol. 2016, 36, 103-111. [CrossRef]

31. Liao, W.; Ning, Z.; Chen, L.; Wei, Q.; Yuan, E.; Yang, J.; Ren, J. Intracellular antioxidant detoxifying effects of diosmetin on 2,2-Azobis(2-amidinopropane) dihydrochloride (AAPH)-induced oxidative stress through inhibition of reactive oxygen species generation. J. Agric. Food Chem. 2014, 62, 8648-8654. [CrossRef] [PubMed]

32. Hu, W.; Wang, G.; Shen, T.; Wang, Y.; Hu, B.; Wang, X.; Wu, L.; Li, P.; Ji, L. Chemical composition, antioxidant and cytoprotective activities of lotus receptacle. Hortic. Environ. Biotechnol. 2015, 56, 712-720. [CrossRef]

33. Lu, Y.; Wu, N.; Fang, Y.; Shaheen, N.; Wei, Y. An automatic on-line 2,2-diphenyl-1-picrylhydrazyl-high performance liquid chromatography method for high-throughput screening of antioxidants from natural products. J. Chromatogr. A 2017, 1521, 100-109. [CrossRef]

34. Ksouri, R.; Falleh, H.; Megdiche, W.; Trabelsi, N.; Mhamdi, B.; Chaieb, K.; Bakrouf, A.; Magné, C.; Abdelly, C. Antioxidant and antimicrobial activities of the edible medicinal halophyte Tamarix gallica L. and related polyphenolic constituents. Food Chem. Toxicol. 2009, 47, 2083-2091. [CrossRef] [PubMed]

35. Baek, K.S.; Yi, Y.S.; Son, Y.J.; Yoo, S.; Sung, N.Y.; Kim, Y.; Hong, S.; Aravinthan, A.; Kim, J.H.; Cho, J.Y. In vitro and in vivo anti-inflammatory activities of Korean Red Ginseng-derived components. J. Ginseng Res. 2016, 40, 437-444. [CrossRef]

Sample Availability: Samples of the compounds 1-3 are available from the authors.

(C) 2019 by the authors. Licensee MDPI, Basel, Switzerland. This article is an open access article distributed under the terms and conditions of the Creative Commons Attribution (CC BY) license (http://creativecommons.org/licenses/by/4.0/). 